\title{
Review
}

\section{The MPTP Story}

\author{
J. William Langston* \\ Parkinson's Institute, Sunnyvale, CA, USA
}

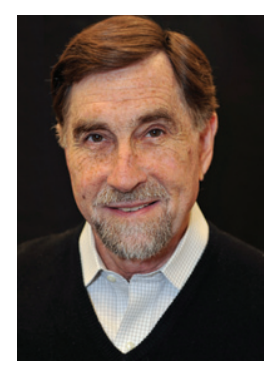

Dr. Langston is the Scientific Director, Chief Scientific Officer and Founder of the Parkinson's Institute in Sunnyvale, California. A graduate of the University of Missouri School of Medicine, he served as faculty at Stanford University Medical School and Chairman of Neurology at Santa Clara Valley Medical Center in San Jose, California before founding the Parkinson's Institute. He gained international recognition in 1980s for the discovery of the link between MPTP and Parkinson's disease, which triggered a renaissance of the basic and clinical research in Parkinson's disease. He authored nearly 400 publications, most of which are on Parkinson's disease and is a founding member of the Scientific Advisory Board for the Michael J Fox Foundation for Parkinson's Research.

\begin{abstract}
The identification of MPTP, a relatively simple compound which causes selective degeneration of the substantia nigra after systemic administration, has had an a significant impact on the understanding and treatment of Parkinson's disease (PD) over the last 30 years. This article is prefaced by the intriguing "medical detective story" that lead to the discovery of the biological effects of MPTP in humans. The steps that lead to the unraveling its mechanism of action and their impact on research into pathways underlying nigrostriatal degeneration are reviewed. The impact of the animal models that have been developed utilizing MPTP is also described with a focus on the translational implications of MPTP-related research. These include use of MAO-B inhibitors aimed at neuroprotection in PD and the importance of a stable primate model for PD which was utilized to better understand the circuitry of the basal ganglia, and the identification of the subthalamic nucleus as a target for deep brain stimulation. Finally, the results of a broad range of epidemiologic studies aimed as assessing the impact of environmental factors in PD that have been inspired by MPTP are summarized, including the discovery of other neurotoxicants (rotenone and paraquat) with parkinsonogenic effects. Overall, this article attempts to describe how the discovery of this nigral neurotoxicant began, where it is currently, and what the future may hold.
\end{abstract}

\footnotetext{
${ }^{*}$ Correspondence to: J. William Langston, Parkinson's Institute, Sunnyvale, CA, USA. E-mail: JWLANGSTON@ parkinsonsinstitute.org.
} 


\section{PART 1: PROLOGUE}

In 1982, I was working as Director of Neurology at the Santa Clara Valley Medical Center in San Jose, CA, which had recently become a Stanford teaching facility. One morning in July I had just returned to my office after morning rounds when I received a call from our chief resident: "Dr. Langston, you have to come down here, I've never seen anything like it, and no one is sure what this patient has". At first I was annoyed with the interruption as I had just poured a nice cup of coffee and was settling down to read the morning's batch of EEGs. Yet I agreed to come down immediately given the resident's sense of urgency the coffee and EEGs would have to wait. Little did I know that this day would change the direction of my career.

When I arrived, I learned that our neurology residents were evaluating a patient who had just been admitted to the locked psychiatry unit of our hospital with a diagnosis of catatonic schizophrenia. A lively argument had broken out between the psychiatrists and our neurology house-staff over the diagnosis of this patient, who was almost totally unresponsive yet eerily appeared to be alert. Ironically, the psychiatrists were convinced the patient had a neurologic disorder while the neurology residents argued the disorder was psychiatric in nature.

The patient's condition was indeed extraordinary. He was clearly awake, but had virtually no spontaneous movement, and exhibited "waxy flexibility" (when his arm was involuntarily raised, it would stay in the position for a prolonged period of time). Because we had the only locked care psychiatric unit in the county, I had actually seen a number patients with catatonic schizophrenia, something that is less common these days. The answer came quickly. In my experience, when passively flexing the wrist or elbow of a catatonic patient, there is a distinct feeling of irregular active resistance. This patient had the "lead pipe rigidity" with the "cog-wheeling" of Parkinson's disease. Indeed he looked like a textbook case of advance PD before the days of levodopa. But this case didn't fit either answer. He was in his early forties, and his symptoms came on literally overnight. We had a first class "medical mystery" on our hands.

This mystery would unfold in what has been called "a trial of ironies" [1]. Through multiple leads, news media alerts, police assistance, and a bit of luck, we rapidly discovered six similarly affected cases; some of whom lived in different cities and had no connections to each other. They did have one thing in common - all had recently used a new "synthetic heroin" that had hit the streets in multiple northern Californian towns as part of what became known as "the designer drug phenomena". The parkinsonism in our original seven patients exhibited virtually all of the motor features of typical Parkinson's disease, including tremor (very severe in one), and asymmetry of findings [2]. They even exhibited non-motor aspects of the disease such as facial seborrhea and mild deficits in higher cognitive function (e.g., executive function) [3]. Furthermore, these patients all had a dramatic and near immediate response to L-dopa. Several of them experienced levodopa dyskinesias (LIDs) (one within six weeks) identical to that seen in PD, which in some cases became dose-limiting.

We were able to obtain samples of the synthetic heroin through police raids and friendly dealers, and eventually obtained a batch that was comprised of almost pure 1-methyl-4-phenyl-1,2,3,6tetrahydropyridine (MPTP), a byproduct of the synthesis of 1-methyl-4-phenyl-4-propionoxypiperidine (MPPP). This meperidine analog had been synthesized in 1947 by Ziering and Lee [4] but never commercialized or even controlled (thus not illegal to make and even sell). We also found a case similar to ours that had been published in the first issue of Psychiatry Research in 1979 [5]. The offending agent was never identified in this report, although the paper gave us some clues as to where to look.

We published these cases in Science in 1983 [6], identifying MPTP as the likely cause of permanent parkinsonism in these patients, and suggested that it was toxic to the zona compacta of the substantia nigra based on the clinical picture (pure parkinsonism) and the neuropathology of the single case reported earlier. I had almost forgotten this "in press" paper, when, on the day it was published, we were deluged with calls from scientists from all around the world asking where they could get MPTP for research purposes. I was surprised, as we had stated in the introduction of our Science paper, that it was commercially available through Aldrich Chemical. We later learned that the company had sold out of MPTP within hours of the publication. When it did come out again, the price had increased almost 100 fold.

As I began to think about it, I realized that the discovery of such a simple molecule that induced virtually all of the motoric, and some non-motor, features of Parkinson's disease would likely have an impact in many other areas of research. Certainly it would provide a new tool to study nigrostriatal degeneration and ways to prevent it, and it would 
likely provide a new animal model for the disease. This seemed particularly powerful since we knew exactly what MPTP-induced parkinsonism looked like in humans, both in terms of clinical appearance, and in response to L-dopa, including its side effects. Put another way, we had the human model of the animal model of the human disease. Finally, alongside the discovery of the biologic effects of MPTP, a very simple chemical moiety proved to have a metabolite remarkably similar to paraquat (an herbicide used world-wide), an observation that would lead to an renaissance in the epidemiology of the disease. Then there was the great and wonderful question to how this neurotoxicant worked. I was hooked - I had to give up my teaching position and see how far this fascinating little molecule could take us toward solving PD. It would be (and still is) an exciting and productive adventure. For a much more detailed account of this story (with all its twists and turns) please see the book The Case of the Frozen Addicts (Langston and Palfreman, IOS Press, 2014).

\section{PART 2: MECHANISM OF ACTION: FROM SELECTIVITY TO TARGETING MITOCHONDRIA}

After the discovery of the parkinsonogenic effects of MPTP, there was an explosion of research aimed at determining if this relatively small pyridine moiety could so selectively knock out much of the pars compacta of the substania nigra. Indeed at first it seemed total mystery - a second "scientific detective story" if you will. The first piece of the puzzle came from the discovery that MPTP itself was not toxic at all, although, as a lipophilic compound, it could pass into the brain. We found that once in the brain, it was rapidly converted to what proved to be the toxic metabolite, 1-methyl-4-phenylpyridinium or MPP+ [7], an observation that was quickly confirmed by Markey and colleagues [8]. Shortly thereafter and completely unexpectedly, it was found that this biotransformation was mediated by monoamine oxidase $[9,10]$. Heikkila and his colleagues [11] narrowed this down further by showing that MAO B, but not MAO A was responsible for this biotransformation, an observation that has since been confirmed repeatedly.

As potentially interesting as these observations were, there was still much to be explained. For example, where was MPTP being biotransformed into $\mathrm{MPP}+$ within the brain? It turned out that astrocytes were the likely culprits [12] (although other sites including serotonergic neurons may participate [13]), but this simply raised other questions. Why weren't astrocytes themselves being killed making MPP+? Why were the dopaminergic neurons being so selectively targeted? Once again the answer came as a surprise - MPP+ was an excellent substrate for the DA uptake site [13], and thus selectively taken up and concentrated into DA neurons, whereas astrocytes apparently released rather than concentrating it to toxic levels. Interestingly, the ventral tegmental area (VTA) dopaminergic neurons are largely spared even though they also have dopamine uptake sites (possible explanations include differences in uptake affinity [14] or the presence of calbindin [15] in VTA neurons, which in some way may be protective). Once taken up by nigral neurons MPP+, it becomes highly concentrated in mitochondria against a concentration gradient via what appears to be a novel uptake system, which is energized by the transmembrane potential [16]. Once it reaches toxic levels in mitochondria, it has been repeatedly shown to inhibit the Complex 1 of the mitochondrial respiratory chain $[17,18]$. This of course could have a number of consequences including a decline in ATP [19] and/or marked free radical generation that would result. Interestingly, these cells seem to have a friend in the vesicular monoamine transporter, which has also been shown to take up and store $\mathrm{MPP}+$, which could represent a protective mechanism [20]. On the other hand, it has been report in in-vitro that MPP+ causes redistribution of vesicular DA to the cytoplasm, which in turn may be responsible for MPTP-induced toxic reactive oxygen species (ROS) [22]. It has subsequently been reported that moderate MPTP exposure in non-human primates damages vesicular monoamine transportertype 2 , which reduces in dopamine storage within the cell, thereby increasing cytosolic dopamine (leading to subsequent ROS generation, again suggesting that this is key pathological event in retrograde degenerations of DA neurons [21]). Importantly, this mechanism has been highlighted in humans by Lotharius and Brundin [22]; these investigors, using positron emission tomography, have identified what appears to be a very similar mechanism that could lead to cell death in patients with PD. This study implicates alpha-synuclein in the process (also see Part 5 for more on alpha-synuclein and MPTP).

Given that mitochondria are ultimately targeted by MPP+, it was not long before researchers began to explore the possibility that similar deficits might exist in PD patients. Indeed, deficits in mitochon- 
drial NADH CoQ1 reductase (Complex 1) have been reported in the substantia nigra of patients with PD [23] (but not with other neurodegenerative diseases [24]), as well as deficiencies Complex I,II, and IV in muscle PD patients [25], and Complex I and II in lymphocytes and platelets from patients with PD, including those with early disease (platelets) [26]. These studies have also sparked an interest in the role of mitochondrial DNA (mtDNA) [27, 28] in $\mathrm{PD}$, which continues to this day. The interest in mitochondrial dysfunction in PD is not only limited to sporadic PD, but it is also implicated in rare, inherited genetic forms of PD (e.g., mutations in LRRK2 [29] parkin, DJ1 and PINK1 [30] have been suggested to affect mitochondria). Indeed, mitochondrial dysfunction seems to be a recurring thread through many aspects of both genetic and sporadic parkinsonism.

Importantly, mitochondrial research has not been restricted to the laboratory, and a number of clinical trials aimed at improving mitochondrial function have been carried out [31], including such agents as coenzyme Q10 [32], MitoQ [33], rasagiline [34], EPI589 (ClinicalTrials.gov Identifier NCT0246260), and even a ketogenic diet (ClinicalTrials.gov Identifier: NCT01364545) and ursodeoxycholic Acid (ClinicalTrials.gov Identifier: NCT02967250).

\section{PART 3: MODELING PARKINSON'S DISEASE}

Given how similar the effects of MPTP were to typical PD in humans, and the fact that a truly good PD animal model was not available, from a research standpoint this seemed like a golden opportunity. The first attempts to generate MPTP-induced parkinsonism in monkeys were published in 1984 [35, 36]. These studies showed conclusively that monkeys develop virtually all of the motor symptoms seen in humans and that these symptoms were levodopa responsive. Most importantly, the monkeys exhibited a dramatic loss of dopaminergic neurons in the substantia nigra, pars compacta [35, 37]. Interestingly, the VTA was largely spared [38], just as it is in PD. Since that time, there have been between 5 and 7 thousand publications on virtually all aspects of MPTP. The primate MPTP model has been widely used to study the effects of drugs targeting the symptoms of PD, including levodopa, dopamine agonists, amantadine and many others, as well as side-effects including levodopa induced dyskinesia [39]. In regard to the latter, our group has even found that nicotine suppresses dyskinesias [40], an area which continues to be of interest. On the other hand, it still remains unclear how useful this model is in the discovery of disease-modifying agents [39].

At first it was generally thought that only primates were susceptible to the effects of MPTP, as rats and mice seemed resistant to MPTP neurotoxicity. In regard to rats, the mystery was solved when it was found that rats had very high levels of MAO in the blood brain barrier, and were effectively converting MPTP to MPP+, which is not lipophilic and therefor poorly permeates the brain $[41,42]$. Mice were intermediate in this ability, and human microvessels were the poorest of all.

As mice allowed moderate amounts of MPTP into the brain one might have predicted that they would experience at least some toxicity, and this indeed proved to the case [43]. As a result, many studies using MPTP/MPP+ have been carried out in mice over the years as they are much more accessible and inexpensive. However, research utilizing MPTP has not been limited to warm-blooded vertebrates; indeed the list is quite long, including zebrafish [44], C. Elegans [45, 46], and even the salamander [47].

Another novel approach for disease modeling is what we have called "model fusion" [48]. This approach involves combining transgenic mouse models and MPTP exposure to better explore the factors that could lead to the nigral degeneration in PD (or prevent it). The list of transgenic mice that are resistant to MPTP include those with increased $\mathrm{Cu} / \mathrm{Zn}$ superoxide dismutase activity [49], knockout of p53 [50], VMAT2 knockout [51], expressing Bcl-2 [52], metallothionein over-expression (probably by increase coenzyme Q10 production) [53], increased GFAP-Nrf2 in astrocytes [54], overexpression of parkin (possibly by protection of mitochondria and reduction of alpha-synuclein) and DJ-1) [55].

\section{PART 4: TWO EXAMPLES OF THE TRANSLATIONAL IMPACT OF MPTP ON THERAPIES FOR PD}

\footnotetext{
1. The beginning of the "age of neuroprotection". The MAO B Story

After it was found that MAO inhibitors could block the toxic effects of MPTP, the next set of experiments were obvious: If MPP+ was indeed the toxic metabolite, then blocking MAO should prevent parkinsonism in non-human primates. Our first experiment utilized
} 
the non-selective MAO inhibitor pargyline, and the results were dramatic, as both the parkinsonism and loss of DA neurons in pars compact were completely prevented in the primate model of MPTP induced parkinsonism [56]. And thus began the age of "neuroprotection" research, which continues to thrive to this day (see below). This finding was quickly confirmed in non-human primates by Cohen et al. [57] and in rodents, where dopamine depletion caused by MPTP was prevented by selective MAO B inhibitors but not selective MAO A inhibitors [11]. This was important because MAO A inhibitors generally are not use in PD patients because of the so-called "cheese effect" [58] as this enzyme normally blocks the catabolism of tyramine in the gut, thus avoiding large amounts of tyramine to pass through and causing profound increases in blood pressure [59].

These observations inspired us to carry out the first prospective clinical trial aimed at slowing PD [60] (or any neurodegenerative disease of aging for that matter). We found that "de-novo" patients treated with selegiline could go nearly twice as long as "de-novo" patients given placebo before requiring levodopa therapy. While this looked very promising and served as a prototype for trial design, things became more controversial after we and our colleagues carried out a much larger study (800 patients as opposed to just 54 patients in our original study [60]) which became known as DATATOP [61]. This trial used the same design as our trial, but had a third arm that included alpha-tocopherol, to test its antioxidant effects in PD. While the alpha-tocopherol had no effects in delaying disability, the selegiline arm show a highly significant effect in delaying the need for L-DOPA treatment over controls $\left(\mathrm{P}>10^{-9}\right)$. While these results were impressive, there proved to be a confounding factor, as the study also showed that selegiline had a very mild symptomatic effect during the first 3 months of starting the drug (we could not see this in our original study because of the smaller size and lack of power for such a small symptomatic benefit). Critics argued that even a small symptomatic effect could have imitated a disease modifying effect. Having anticipated this issue (as MAO B inhibitors could block catabolism of and thereby conserve dopamine) all patients were washed out for a month after the trials ended. While the selegiline group maintained an advantage over the placebo group after a month off drugs, it was then argued the wash-out was not long enough, and thus the interpretation of the outcome of the DATATOP study was controversial, and remains so to this day.
That wasn't the end of the story. Teva Pharmaceuticals Industries Ltd later carried a very large trial using a second generation MAO B inhibitor, rasagiline, and a new design which utilized a "delay start design" in which the active drug was started first, and the placebo group was started 6 months later [62], thus avoiding the potential controversies of having a wash out period (as this was actually a "wash-in study"). If the drug was disease modifying, then the severity of symptoms for the PD patients who were in the delayed start group should never quite catch up to the early start group. The results of this study were compelling in that the delayed start group never did catch up when using a $1 \mathrm{mg}$ per day dose. But once again, there was a "fly in the ointment" as this was not the case with the $2 \mathrm{mg}$ per day group, thus confounding the results to the point that the FDA did not accept this second generation MAO B inhibitor as disease modifying, although it has been approved for early treatment of PD, as in "de novo" patients the drug clearly delays disability during the first year of treatment [62]. Also, see addendum at the end of this article.

In closing this section, two points should be made. First, the delayed start design has to some degree been validated by a trial with pramipexole know as PROUD, a symptomatic drug for PD [63]. In this study, when the placebo group was "washed in" at 6 months, they immediately caught up with the early start group, suggesting that there was no "disease modifying" advantage to an early start with pramipexole, which should have been the case if the drug was disease modifying. As a final point, while we introduce the term "neuroprotective" in our early reports on the effects of MPTP, this term is probably inappropriate for any trials in humans. This is because while we can measure cell loss in animal models of PD, we really cannot do so in patients - the technology is not there yet to do this in living human beings. In view of this, the terms "disease modifying" (or "delaying disability" - a clinical observation) are probably more appropriate for human studies.

\section{Therapeutic implications of understanding} basal ganglia circuitry (DBS):

While the MPTP non-human primate model of PD has been widely and successfully used to study symptomatic drugs for PD and even drug side-effects such as LIDs, it also provided a stable model for elucidating basal ganglia circuitry and the effect of nigrostriatal degeneration on those pathways. This model was very effectively used by Mahlon Delong [64] to map out the direct and indirect pathways 
of the basal ganglia. One finding that proved to be of great translational value was the observation of over-activity of the subthalamic nucleus after MPTPinduced degeneration of the substantia nigra [65]. This resulted in a seminal paper in which he and his colleagues [66] showed that MPTP-induced lesions of the subthalamic nucleus (STN) in MPTP-lesioned primates abolished all the major motor components of their parkinsonism. While extending this procedure to patients with PD was a very exciting prospect, it has long been know that lesions in this area can cause hemiballismus, making it a potentially risky procedure. It would be up to Benabid and his colleagues [67] to show that deep brain stimulation of the STN was safe and worked in patients with PD. This procedure has now considered a major step forward in the treatment of PD (for a detailed review see Wichmann et al. [68] or the article by M. Hariz on DBS in this issue of the Journal of Parkinson's disease [79]).

\section{PART 5: THE ENVIRONMENTAL HYPOTHESIS OF PD}

Over the last two centuries the pendulum of opinion has swung widely as to whether the cause of PD was due to genetics or environment causes [69]. While MPTP has not yet been found in the native environment, beginning in the 1980s the pendulum swung dramatically in the direction of the environmental hypothesis, spurred not only by the observation that a simple pyridine (MPTP) could induce so many of the features of PD, but also the striking similarity between its toxic metabolite, $\mathrm{MPP}+$ and paraquat (differing only by one methyl group) [70], an herbicide that is used worldwide. Since that time, a large number of studies have shown pesticide exposure is a risk factor for PD [71]. Interesting, this risk is enhanced by the presence of certain genetic variants [72], consistent to the adage that "genetics load the gun, but environment pulls the trigger". Exposure to a naturally occurring pesticide known as rotenone (a so-called organic pesticide as it is found in plant legumes) has also been found to increase the risk for PD. It is important to note that both of these compounds have been show to selectively damage the nigrostriatal system in rodents [73]. While paraquat acts through rexo-cycling, remarkably rotenone affects mitochondrial Complex 1 (NADH dehydrogenase binding site) [74] similar to MPP+, once again pointing to mitochondrial dysfunction as a player in the complex sequence of events that lead to nigrostriatal damage in PD.

While great interest continues in the epidemiology of PD, in the mid-1990s, genetics would again ascend as a major focus of interest in the PD field with the discovery of the first monogenic form of Lewy Body parkinsonism [75] (this was the discovery of the A53T mutation in the alpha-synuclein gene, which is covered in detail in the article by Nussbaum in this issue [77]). Since then alpha-synuclein has become a major therapeutic target in PD. Therefore, it's notable MPTP exposure in primates leads to alterations in alpha-synuclein expression in the substantia nigra [76], as well as inducing pathological alterations in the protein.

\section{PART 6: EPILOGUE}

In this article, I have highlighted some of the ways the discovery of the biologic effects of MPTP has contributed to research in the field of PD, though there are of course many more that cannot be covered in the bounds of this article. It is worth pointing out that the use of this compound as a research tool thrives to this day. For example, since its discovery, through to 2016, there have been over 500 reports of compounds or approaches aimed at modifying or preventing MPTP toxicity in warm blooded vertebrates in the search for new drugs that might target the underlying mechanism of nigrostriatal degeneration and possibly lead to targets for disease modification. Many have identified such familiar targets as mitochondria dysfunction, inflammation and oxidative stress, but many are quite novel. It seems likely that there are some valuable clues in the work that is already published and in those yet to come.

Finally, I would like to conclude with some closing thoughts: If there is an overarching lesson from this story for clinicians, it is to never forget the power of clinical observation. It is critical to never assume anything and maintain a high level of curiosity when encountering something that doesn't fit a normal diagnostic mold. In this modern age of high technology, it is hard to believe that paying attention to a single patient could ultimately lead to new pathways for research for an entire disease, but it can.

\section{ADDENDUM}

At the time this manuscript was submitted, a new study was published in this journal [78] showing 
for the first time that the extended use of MAO-B inhibitors (over a 7 year period) slows decline in PD patients. Thus the MAO-B story in PD continues unabated.

\section{REFERENCES}

[1] Lewin R (1984) Trail of ironies to Parkinson's disease. Science, 224, 1083-1085.

[2] Ballard PA, Tetrud JW, \& Langston JW (1985) Permanent human parkinsonism due to 1-methyl-4-phenyl-1,2,3,6tetrahydropyridine (MPTP): Seven cases. Neurology, 35, 949-956.

[3] Stern Y, Tetrud JW, Martin WR, Kutner SJ, \& Langston JW (1990) Cognitive change following MPTP exposure. Neurology, 40, 261-264.

[4] Ziering A, \& Lee J (1947) Piperidine derivatives; 1,3dialkyl-4-aryl-4-acyloxypiperidines. J Org Chem, 12, 911-914.

[5] Davis GC, Williams AC, Markey SP, Ebert MH, Caine ED, Reichert CM, \& Kopin IJ (1979) Chronic Parkinsonism secondary to intravenous injection of meperidine analogues. Psychiatry Res, 1, 249-254.

[6] Langston JW, Ballard P, Tetrud JW, \& Irwin I (1983) Chronic Parkinsonism in humans due to a product of meperidine-analog synthesis. Science, 219, 979-980.

[7] Langston JW, Irwin I, Langston EB, \& Forno LS (1984) 1-Methyl-4-phenylpyridinium ion (MPP+): Identification of a metabolite of MPTP, a toxin selective to the substantia nigra. Neurosci Lett, 48, 87-92.

[8] Markey SP, Johannessen JN, Chiueh CC, Burns RS, \& Herkenham MA (1984) Intraneuronal generation of a pyridinium metabolite may cause drug- induced parkinsonism. Nature, 311, 464-467.

[9] Chiba K, Trevor A, \& Castagnoli Jr N (1984) Metabolism of the neurotoxic tertiary amine, MPTP, by brain monoamine oxidase. Biochem Biophys Res Commun, 120, 574-578.

[10] Castagnoli Jr N, Chiba K, \& Trevor AJ (1985) Potential bioactivation pathways for the neurotoxin 1-methyl-4phenyl- 1,2,3,6-tetrahydropyridine (MPTP). Life Sci, 36, 225-230.

[11] Heikkila RE, Manzino L, Cabbat FS, \& Duvoisin RC (1984) Protection against the dopaminergic neurotoxicity of 1-methyl-4-phenyl- 1,2,5,6-tetrahydropyridine by monoamine oxidase inhibitors. Nature, 311, 467-469.

[12] Ransom BR, Kunis DM, Irwin I, \& Langston JW (1987) Astrocytes convert the parkinsonism inducing neurotoxin, MPTP, to its active metabolite, MPP+. Neurosci Lett, $\mathbf{7 5}$, 323-328.

[13] Shen RS, Abell CW, Gessner W, \& Brossi A (1985) Serotonergic conversion of MPTP and dopaminergic accumulation of MPP+. FEBS Lett, 189, 225-230.

[14] Blanchard V, Raisman-Vozari R, Vyas S, Michel PP, Javoy-Agid F, Uhl G, \& Agid Y (1994) Differential expression of tyrosine hydroxylase and membrane dopamine transporter genes in subpopulations of dopaminergic neurons of the rat mesencephalon. Brain Res Mol Brain Res, 22, 29-38.

[15] Lavoie B, \& Parent A (1991) Dopaminergic neurons expressing calbindin in normal and parkinsonian monkeys. Neuroreport, 2, 601-604.
[16] Ramsay RR, Dadgar J, Trevor A, \& Singer TP (1986) Energy-driven uptake of N-methyl-4-phenylpyridine by brain mitochondria mediates the neurotoxicity of MPTP. Life Sci, 39, 581-588.

[17] Ramsay RR, Salach JI, \& Singer TP (1986) Uptake of the neurotoxin 1-methyl-4-phenylpyridine (MPP+) by mitochondria and its relation to the inhibition of the mitochondrial oxidation of NAD+-linked substrates by MPP+. Biochem Biophys Res Commun, 134, 743-748.

[18] Ramsay RR, Kowal AT, Johnson MK, Salach JI, \& Singer TP (1987) The inhibition site of MPP+, the neurotoxic bioactivation product of 1- methyl-4-phenyl1,2,3,6-tetrahydropyridine is near the Q-binding site of NADH dehydrogenase. Arch Biochem Biophys, 259, 645649.

[19] Chan P, DeLanney LE, Irwin I, Langston JW, \& Di Monte D (1991) Rapid ATP loss caused by 1-methyl-4-phenyl1,2,3,6-tetrahydropyridine in mouse brain. J Neurochem, 57, 348-351.

[20] Speciale SG, Liang CL, Sonsalla PK, Edwards RH, \& German DC (1998) The neurotoxin 1-methyl-4phenylpyridinium is sequestered within neurons that contain the vesicular monoamine transporter. Neuroscience, 84, 1177-1185.

[21] Chen MK, Kuwabara H, Zhou Y, Adams RJ, Brasic JR, McGlothan JL, Verina T, Burton NC, Alexander M, Kumar A, Wong DF, \& Guilarte TR (2008) VMAT2 and dopamine neuron loss in a primate model of Parkinson's disease. J Neurochem, 105, 78-90.

[22] Lotharius J, \& Brundin P (2002) Pathogenesis of Parkinson's disease: Dopamine, vesicles and alpha-synuclein. Nat Rev Neurosci, 3, 932-942.

[23] Schapira AH, Cooper JM, Dexter D, Clark JB, Jenner P, \& Marsden CD (1990) Mitochondrial complex I deficiency in Parkinson's disease. J Neurochem, 54, 823-827.

[24] Schapira AH, Mann VM, Cooper JM, Dexter D, Daniel SE, Jenner P, Clark JB, \& Marsden CD (1990) Anatomic and disease specificity of NADH CoQ1 reductase (complex I) deficiency in Parkinson's disease. J Neurochem, 55, 21422145.

[25] Bindoff LA, Birch-Machin MA, Cartlidge NE, Parker Jr WD, \& Turnbull DM (1991) Respiratory chain abnormalities in skeletal muscle from patients with Parkinson's disease. J Neurol Sci, 104, 203-208.

[26] Haas RH, Nasirian F, Nakano K, Ward D, Pay M, Hill R, \& Shults CW (1995) Low platelet mitochondrial complex I and complex II/III activity in early untreated Parkinson's disease. Ann Neurol, 37, 714-722.

[27] Schapira AH, Holt IJ, Sweeney M, Harding AE, Jenner P, \& Marsden CD (1990) Mitochondrial DNA analysis in Parkinson's disease. Mov Disord, 5, 294-297.

[28] Di Monte DA (1991) Mitochondrial DNA and Parkinson's disease. Neurology, 41, 38-42; discussion 42-33.

[29] Sanders LH, Laganiere J, Cooper O, Mak SK, Vu BJ, Huang YA, Paschon DE, Vangipuram M, Sundararajan R, Urnov FD, Langston JW, Gregory PD, Zhang HS, Greenamyre JT, Isacson O, \& Schule B (2014) LRRK2 mutations cause mitochondrial DNA damage in iPSCderived neural cells from Parkinson's disease patients: Reversal by gene correction. Neurobiol Dis, 62, 381-386.

[30] Gehrke S, Wu Z, Klinkenberg M, Sun Y, Auburger G, Guo S, \& Lu B (2015) PINK1 and Parkin control localized translation of respiratory chain component mRNAs on mitochondria outer membrane. Cell Metab, 21, 95-108. 
[31] Schapira AH (2012) Targeting mitochondria for neuroprotection in Parkinson's disease. Antioxid Redox Signal, 16, 965-973.

[32] Parkinson Study Group QEI, Beal MF, Oakes D, Shoulson I, Henchcliffe C, Galpern WR, Haas R, Juncos JL, Nutt JG, Voss TS, Ravina B, Shults CM, Helles K, Snively V, Lew MF, Griebner B, Watts A, Gao S, Pourcher E, Bond L, Kompoliti K, Agarwal P, Sia C, Jog M, Cole L, Sultana M, Kurlan R, Richard I, Deeley C, Waters CH, Figueroa A, Arkun A, Brodsky M, Ondo WG, Hunter CB, JimenezShahed J, Palao A, Miyasaki JM, So J, Tetrud J, Reys L, Smith K, Singer C, Blenke A, Russell DS, Cotto C, Friedman JH, Lannon M, Zhang L, Drasby E, Kumar R, Subramanian T, Ford DS, Grimes DA, Cote D, Conway J, Siderowf AD, Evatt ML, Sommerfeld B, Lieberman AN, Okun MS, Rodriguez RL, Merritt S, Swartz CL, Martin WR, King P, Stover N, Guthrie S, Watts RL, Ahmed A, Fernandez HH, Winters A, Mari Z, Dawson TM, Dunlop B, Feigin AS, Shannon B, Nirenberg MJ, Ogg M, Ellias SA, Thomas CA, Frei K, Bodis-Wollner I, Glazman S, Mayer T, Hauser RA, Pahwa R, Langhammer A, Ranawaya R, Derwent L, Sethi KD, Farrow B, Prakash R, Litvan I, Robinson A, Sahay A, Gartner M, Hinson VK, Markind S, Pelikan M, Perlmutter JS, Hartlein J, Molho E, Evans S, Adler CH, Duffy A, Lind M, Elmer L, Davis K, Spears J, Wilson S, Leehey MA, Hermanowicz N, Niswonger S, Shill HA, Obradov S, Rajput A, Cowper M, Lessig S, Song D, Fontaine D, Zadikoff C, Williams K, Blindauer KA, Bergholte J, Propsom CS, Stacy MA, Field J, Mihaila D, Chilton M, Uc EY, Sieren J, Simon DK, Kraics L, Silver A, Boyd JT, Hamill RW, Ingvoldstad C, Young J, Thomas K, Kostyk SK, Wojcieszek J, Pfeiffer RF, Panisset M, Beland M, Reich SG, Cines M, Zappala N, Rivest J, Zweig R, Lumina LP, Hilliard CL, Grill S, Kellermann M, Tuite P, Rolandelli S, Kang UJ, Young J, Rao J, Cook MM, Severt L, \& Boyar K (2014) A randomized clinical trial of high-dosage coenzyme Q10 in early Parkinson disease: No evidence of benefit. JAMA Neurol, 71, 543-552.

[33] Snow BJ, Rolfe FL, Lockhart MM, Frampton CM, O'Sullivan JD, Fung V, Smith RA, Murphy MP, Taylor KM, \& Protect Study G (2010) A double-blind, placebo-controlled study to assess the mitochondriatargeted antioxidant MitoQ as a disease-modifying therapy in Parkinson's disease. Mov Disord, 25, 1670-1674.

[34] Jenner P, \& Langston JW (2011) Explaining ADAGIO: A critical review of the biological basis for the clinical effects of rasagiline. Mov Disord, 26, 2316-2323.

[35] Burns RS, Markey SP, Phillips JM, \& Chiueh CC (1984) The neurotoxicity of 1-methyl-4-phenyl-1,2,3,6tetrahydropyridine in the monkey and man. Can J Neurol Sci, 11, 166-168.

[36] Langston JW, Langston EB, \& Irwin I (1984) MPTPinduced parkinsonism in human and non-human primatesclinical and experimental aspects. Acta Neurol Scand Suppl, 100, 49-54.

[37] Langston JW, Forno LS, Rebert CS, \& Irwin I (1984) Selective nigral toxicity after systemic administration of 1 methyl-4-phenyl-1,2,5,6-tetrahydropyrine (MPTP) in the squirrel monkey. Brain Res, 292, 390-394.

[38] Jacobowitz DM, Burns RS, Chiueh CC, \& Kopin IJ (1984) N-methyl-4-phenyl-1,2,3,6-tetra-hydropyridine (MPTP) causes destruction of the nigrostriatal but not the mesolimbic dopamine system in the monkey. Psychopharmacol Bull, 20, 416-422.
[39] Fox SH, \& Brotchie JM (2010) The MPTP-lesioned non-human primate models of Parkinson's disease. Past, present, and future. Prog Brain Res, 184, 133-157.

[40] Quik M, Cox H, Parameswaran N, O'Leary K, Langston JW, \& Di Monte D (2007) Nicotine reduces levodopainduced dyskinesias in lesioned monkeys. Ann Neurol, 62, 588-596.

[41] Riachi NJ, Harik SI, Kalaria RN, \& Sayre LM (1988) On the mechanisms underlying 1-methyl-4-phenyl-1,2,3,6tetrahydropyridine neurotoxicity. II. Susceptibility among mammalian species correlates with the toxin's metabolic patterns in brain microvessels and liver. J Pharmacol Exp Ther, 244, 443-448.

[42] Riachi NJ, LaManna JC, \& Harik SI (1989) Entry of 1-methyl-4-phenyl-1,2,3,6-tetrahydropyridine into the rat brain. J Pharmacol Exp Ther, 249, 744-748.

[43] Heikkila RE, Cabbat FS, Manzino L, \& Duvoisin RC (1984) Effects of 1-methyl-4-phenyl-1,2,5,6tetrahydropyridine on neostriatal dopamine in mice. Neuropharmacology, 23, 711-713.

[44] McKinley ET, Baranowski TC, Blavo DO, Cato C, Doan TN, \& Rubinstein AL (2005) Neuroprotection of MPTPinduced toxicity in zebrafish dopaminergic neurons. Brain Res Mol Brain Res, 141, 128-137.

[45] Braungart E, Gerlach M, Riederer P, Baumeister R, \& Hoener MC (2004) Caenorhabditis elegans MPP+ model of Parkinson's disease for highthroughput drug screenings. Neurodegener Dis, 1, 175-183.

[46] Wang YM, Pu P, \& Le WD (2007) ATP depletion is the major cause of MPP+ induced dopamine neuronal death and worm lethality in alpha-synuclein transgenic C. elegans. Neurosci Bull, 23, 329-335.

[47] Barbeau A, Dallaire L, Buu NT, Veilleux F, Boyer H, de Lanney LE, Irwin I, Langston EB, \& Langston JW (1985) New amphibian models for the study of 1-methyl4-phenyl-1,2,3,6-tetrahydropyridine (MPTP). Life Sci, 36, 1125-1134.

[48] Manning-Bog AB, \& Langston JW (2007) Model fusion, the next phase in developing animal models for Parkinson's disease. Neurotox Res, 11, 219-240.

[49] Przedborski S, Kostic V, Jackson-Lewis V, Naini AB, Simonetti S, Fahn S, Carlson E, Epstein CJ, \& Cadet JL (1992) Transgenic mice with increased $\mathrm{Cu} / \mathrm{Zn}$-superoxide dismutase activity are resistant to N-methyl-4-phenyl1,2,3,6-tetrahydropyridine-induced neurotoxicity. $\mathrm{J} \mathrm{Neu}$ rosci, 12, 1658-1667.

[50] Trimmer PA, Smith TS, Jung AB, \& Bennett Jr JP (1996) Dopamine neurons from transgenic mice with a knockout of the p53 gene resist MPTP neurotoxicity. Neurodegeneration, 5, 233-239.

[51] Takahashi N, Miner LL, Sora I, Ujike H, Revay RS, Kostic V, Jackson-Lewis V, Przedborski S, \& Uhl GR (1997) VMAT2 knockout mice: Heterozygotes display reduced amphetamine- conditioned reward, enhanced amphetamine locomotion, and enhanced MPTP toxicity. Proc Natl Acad Sci U S A, 94, 9938-9943.

[52] Offen D, Beart PM, Cheung NS, Pascoe CJ, Hochman A, Gorodin S, Melamed E, Bernard R, \& Bernard O (1998) Transgenic mice expressing human Bcl-2 in their neurons are resistant to 6-hydroxydopamine and 1-methyl4-phenyl-1,2,3,6- tetrahydropyridine neurotoxicity. Proc Natl Acad Sci U S A, 95, 5789-5794.

[53] Ebadi M, Brown-Borg H, El Refaey H, Singh BB, Garrett S, Shavali S, \& Sharma SK (2005) Metallothionein- 
mediated neuroprotection in genetically engineered mouse models of Parkinson's disease. Brain Res Mol Brain Res, 134, 67-75.

[54] Chen PC, Vargas MR, Pani AK, Smeyne RJ, Johnson DA, Kan YW, \& Johnson JA (2009) Nrf2-mediated neuroprotection in the MPTP mouse model of Parkinson's disease: Critical role for the astrocyte. Proc Natl Acad Sci U S A, 106, 2933-2938.

[55] Bian M, Liu J, Hong X, Yu M, Huang Y, Sheng Z, Fei J, \& Huang F (2012) Overexpression of parkin ameliorates dopaminergic neurodegeneration induced by 1- methyl-4phenyl-1,2,3,6-tetrahydropyridine in mice. PLoS One, 7, e39953.

[56] Langston JW, Irwin I, Langston EB, \& Forno LS (1984) Pargyline prevents MPTP-induced parkinsonism in primates. Science, 225, 1480-1482.

[57] Cohen G, Pasik P, Cohen B, Leist A, Mytilineou C, \& Yahr MD (1984) Pargyline and deprenyl prevent the neurotoxicity of 1-methyl-4-phenyl- 1,2,3,6-tetrahydropyridine (MPTP) in monkeys. Eur J Pharmacol, 106, 209-210.

[58] Sandler M, Glover V, Ashford A, \& Esmail A (1980) The inhibition of tyramine oxidation and the tyramine hypertensive response ("cheese effect") may be independent phenomena. J Neural Transm, 48, 241-247.

[59] Sandler M, Glover V, Ashford A, \& Stern GM (1978) Absence of "cheese effect" during deprenyl therapy: Some recent studies. J Neural Transm, 43, 209-215.

[60] Tetrud JLJ (1989) The effect of Deprenyl (Selegiline) on the Natural History of PD. Science Mag, 1989.pdf. Science Mag.

[61] (1989) Effect of deprenyl on the progression of disability in early Parkinson's disease. The Parkinson Study Group. N Engl J Med 321, 1364-1371.

[62] Olanow CW, Rascol O, Hauser R, Feigin PD, Jankovic J, Lang A, Langston W, Melamed E, Poewe W, Stocchi F, Tolosa E, \& Investigators AS (2009) A double-blind, delayed-start trial of rasagiline in Parkinson's disease. N Engl J Med, 361, 1268-1278.

[63] Schapira AH, McDermott MP, Barone P, Comella CL, Albrecht S, Hsu HH, Massey DH, Mizuno Y, Poewe W, Rascol O, \& Marek K (2013) Pramipexole in patients with early Parkinson's disease (PROUD): A randomised delayed-start trial. Lancet Neurol, 12, 747-755.

[64] DeLong MR (1990) Primate models of movement disorders of basal ganglia origin. Trends Neurosci, 13, 281-285.

[65] Bergman H, Wichmann T, Karmon B, \& DeLong MR (1994) The primate subthalamic nucleus. II. Neuronal activity in the MPTP model of parkinsonism. J Neurophysiol, 72, 507-520.

[66] Bergman H, Wichmann T, \& DeLong MR (1990) Reversal of experimental parkinsonism by lesions of the subthalamic nucleus. Science, 249, 1436-1438.

[67] Benabid AL, Pollak P, Gross C, Hoffmann D, Benazzouz A, Gao DM, Laurent A, Gentil M, \& Perret J (1994) Acute and long-term effects of subthalamic nucleus stimulation in Parkinson's disease. Stereotact Funct Neurosurg, 62, 76-84.

[68] Wichmann T, DeLong MR, Guridi J, \& Obeso JA (2011) Milestones in research on the pathophysiology of Parkinson's disease. Mov Disord, 26, 1032-1041.

[69] Goldman SM (2014) Environmental toxins and Parkinson's disease. Annu Rev Pharmacol Toxicol, 54, 141-164.

[70] Sandy MS, Di Monte D, Cohen P, \& Smith MT (1988) Role of active oxygen in paraquat and 1-methyl-4-phenyl1,2,3,6- tetrahydropyridine (MPTP) cytotoxicity. Basic Life Sci, 49, 795-801.

[71] Tanner CM (2010) Advances in environmental epidemiology. Mov Disord, 25(Suppl 1), S58-S62.

[72] Goldman SM, Kamel F, Ross GW, Bhudhikanok GS, Hoppin JA, Korell M, Marras C, Meng C, Umbach DM, Kasten M, Chade AR, Comyns K, Richards MB, Sandler DP, Blair A, Langston JW, \& Tanner CM (2012) Genetic modification of the association of paraquat and Parkinson's disease. Mov Disord, 27, 1652-1658.

[73] Betarbet R, Sherer TB, MacKenzie G, Garcia-Osuna M, Panov AV, \& Greenamyre JT (2000) Chronic systemic pesticide exposure reproduces features of Parkinson's disease. Nat Neurosci, 3, 1301-1306.

[74] Ramsay RR, Krueger MJ, Youngster SK, Gluck MR, Casida JE, \& Singer TP (1991) Interaction of 1-methyl4-phenylpyridinium ion (MPP+) and its analogs with the rotenone/piericidin binding site of NADH dehydrogenase. J Neurochem, 56, 1184-1190.

[75] Polymeropoulos MH, Lavedan C, Leroy E, Ide SE, Dehejia A, Dutra A, Pike B, Root H, Rubenstein J, Boyer R, Stenroos ES, Chandrasekharappa S, Athanassiadou A, Papapetropoulos T, Johnson WG, Lazzarini AM, Duvoisin RC, Di Iorio G, Golbe LI, \& Nussbaum RL (1997) Mutation in the alpha-synuclein gene identified in families with Parkinson's disease [see comments]. Science, 276, 20452047.

[76] Purisai MG, McCormack AL, Langston WJ, Johnston LC, $\&$ Di Monte DA (2005) Alpha-synuclein expression in the substantia nigra of MPTP-lesioned non-human primates. Neurobiol Dis, 20, 898-906.

[77] Nussbaum RL (2017) The identification of alphasynuclein as the first Parkinson disease gene. J Parkinsons Dis, 7, S45-S51.

[78] Hauser RA, Li R, Pérez A, Ren X, Weintraub D, Elm J, Goudreau JL, Morgan JC, Fang JY, Aminoff MJ, Christine CW, Dhall R, Umeh CC, Boyd JT, Stover N, Leehey M, Zweig RM, Nicholas AP, Bodis-Wollner I, Willis A, Kieburtz K, Tilley BC and for the NINDS NET-PD Investigators (2017) Longer duration of MAO-B inhibitor exposure is associated with less clinical decline in Parkinson's disease: An analysis of NET-PD LS1. J Parkinsons Dis, 7, 117-127.

[79] Hariz M (2017) My 25 stimulating years with DBS in Parkinson's disease. J Parkinsons Dis, 7, S35-S43. 